\title{
Cancer-Associated Gene 1 Protein
}

National Cancer Institute

\section{Source}

National Cancer Institute. Cancer-Associated Gene 1 Protein. NCI Thesaurus. Code C139926.

Cancer-associated gene 1 protein $(777 \mathrm{aa}, \sim 90 \mathrm{kDa}$ ) is encoded by the human CAGE1 gene. This protein may play a role in testes development and carcinogenesis. 